\title{
ANALISIS ANTREAN BUS NONPATAS AKAP DAN AKDP JALUR TIMUR TERMINAL TIRTONADI KOTA SURAKARTA
}

\author{
Rosalina Aprilda Situmorang ${ }^{1}$, Sugito ${ }^{2}$, Moch. Abdul Mukid ${ }^{3}$ \\ 1,2,3 Departemen Statistika, Fakultas Sains dan Matematika, Universitas Diponegoro \\ e-mail : sugitostat@gmail.com
}

\begin{abstract}
The queuing system is a set of customers, services and a set of rules governing the arrival of its customers and services. Queue is a waiting phenomenon that is part of everyday human life. The queue is formed if the number of subscribers to be served exceeds the available service capacity. Queue phenomenon one of them seen in the queue nonpatas buses at Terminal Tirtonadi Surakarta. Nonpatas bus lanes studied include nonpurpose buses Surabaya, Karanganyar, Wonogiri, Purwodadi and Pedesaan. The queue displant used is FIFO (First In First Out). For the five nonpatas bus lanes it meets steady state conditions because it has utility value less than 1. The selected model is a model that has the following 4 types of distributions: Erlang, Weibull,

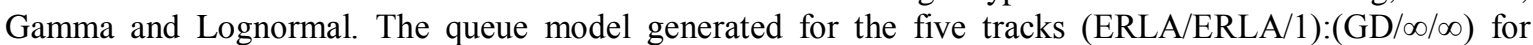

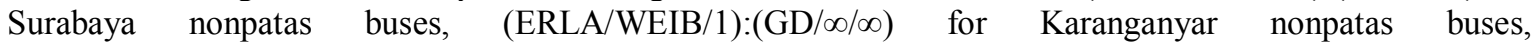

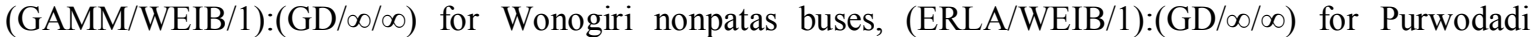

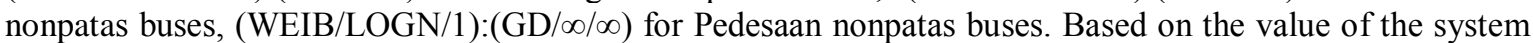
performance measure indicated that the five lines are queue system is good.
\end{abstract}

Keywords: Beta, Erlang, FIFO, Gamma, Steady State Conditions, Lognormal, Queue Model, Queuing Systems, System Performance Measure, Weibull

\section{PENDAHULUAN}

Moda transportasi yang sering digunakan adalah moda transportasi darat salah satunya adalah bus. Alasan paling mendasar yang membuat bus sering digunakan adalah karena kepraktisannya. Selain itu jadwal keberangkatan bus juga banyak. Hal ini membuat jumlah pelanggan bus banyak dan tingkat antrean bus juga tinggi.

Antrean terbentuk jika banyaknya pelanggan yang akan dilayani melebihi kapasitas layanan yang tersedia, sehingga terjadi situasi dimana pelanggan harus antri untuk suatu layanan tersebut. Sistem antrean adalah suatu himpunan pelanggan, pelayanan dan suatu aturan yang mengatur kedatangan para pelanggan dan pelayanannya (Kakiay, 2004).

Antrean merupakan suatu fenomena menunggu yang menjadi bagian dari kehidupan sehari-hari manusia. Terminal Bus Tirtonadi Surakarta merupakan satu-satunya Terminal yang ada di Kota Surakarta dan termasuk sebagai Terminal terbaik di Indonesia. Karena merupakan satu-satunya Terminal di Kota Surakarta sebagian besar masyarakat disana tentu menjadi pelanggan di Terminal Tirtonadi. Terminal terbaik tentu memiliki banyak pelanggan penumpang yang dapat menimbulkan antrean. Sehingga situasi antrean juga ditemukan di Terminal Bus Tirtonadi Kota Surakarta. Salah satu cara untuk mengurangi masalah yang terjadi pada suatu antrean dan mengoptimalkan tingginya tingkat pelayanan di Terminal Bus Tirtonadi adalah dengan menggunakan teori antrean.

Terminal Bus Tirtonadi melayani bus patas dan nonpatas untuk angkutan Antar Kota Dalam Propinsi (AKDP) dan Antar Kota Antar Propinsi (AKAP). Waktu operasional Terminal Tirtonadi adalah 24 jam karena terminal ini merupakan penghubung jalur dari Jawa Timur, Jawa Tengah bagian utara (Semarang), Daerah Istimewa Yogyakarta dan Jawa Barat.

Penelitian ini menggunakan model antrean nonpoisson. Antrean nonpoisson adalah model antrean dimana notasi $a$ atau notasi $b$ nya tidak berdistribusi poisson atau tidak beristribusi eksponensial. Pada antrean nonpoisson jika notasi $a$ nya adalah jumlah 
kedatangan maka bentuk distribusinya nonpoisson dan jika notasi $a$ nya adalah waktu antar kedatangan maka bentuk distribusinya adalah noneksponensial. Demikian juga untuk notasi $b$, jika notasi $b$ nya adalah jumlah pelayanan makan bentuk distribusinya adalah nonpoisson dan jika notasi $b$ nya adalah waktu pelayanan maka bentuk distribusinya dalah noneksponensial.

Penelitian ini membahas tentang persoalan antrean bus akap dan akdp yang terjadi pada jalur timur Terminal Tirtonadi Kota Surakarta, yaitu tentang bagaimana menetukan model antrean bus nonpatas akap dan akdp jalur timur Terminal Tirtonadi Kota Surakarta dan menentukan ukuran kinerja sistem antrean bus nonpatas akap dan akdp jalur timur Terminal Tirtonadi Kota Surakarta.

\section{TINJAUAN PUSTAKA}

\subsection{Gambaran Terminal Bus Tirtonadi Surakarta}

Terminal bus Tirtonadi adalah terminal bus terbesar di Kota Surakarta. Terminal ini terletak di Jl. Jend A Yani 262, Gilingan, Banjarsari Kota Surakarta (Solo) kode pos 57134. Terminal Tirtonadi merupakan area atau wadah untuk angkutan umum untuk menurunkan dan menaikkan penumpang yaitu di jalur kota. Terminal Tirtonadi merupakan jenis terminal tipe A. Dengan kriteria terminal yang mempunyai jumlah kapasitas tampungan yang banyak dan keluasan area yang cukup luas. Terminal ini juga menyediakan fasilitas peristirahatan yang dapat menampung 70 bus. Terminal ini beroperasi 24 jam karena merupakan jalur antara yang menghubungkan angkutan bus dari Jawa Timur (terutama Surabaya dan Banyuwangi) dan Jawa Barat (Bandung). Terminal bus jalur timur adalah yang terminal yang bus-busnya melayani pelanggan dengan tujuan ke arah timur Kota Surakarta yaitu Surabaya, Karanganyar, Wonogiri, Purwodadi dan Pedesaan.

\subsection{Deskripsi Antrean}

Menurut Kakiay (2004), antrean adalah suatu garis tunggu dari sejumlah pelanggan yang memerlukan pelayanan dari satu atau lebih fasilitas pelayanan. Proses antrean (quеиеing process) adalah suatu proses yang berhubungan dengan kedatangan pelanggan pada suatu fasilitas pelayanan, menunggu dalam baris antrean jika belum dapat dilayani, dilayani dan akhirnya meninggalkan fasilitas tersebut sesudah dilayani. Sedangkan sistem antrean adalah suatu himpunan pelanggan, pelayan dan suatu aturan yang mengatur pelayanan kepada pelanggan. Sistem antrean dapat digambarkan sebagai kedatangan pelanggan untuk mendapatkan layanan, menunggu untuk dilayani jika fasilitas pelayanan masih sibuk, mendapatkan pelayanan dan kemudian meninggalkan sistem setelah pelanggan dilayani.

\section{3. $\quad$ Faktor Sistem Antrean}

Menurut Kakiay (2004) ada beberapa faktor penting yang terkait erat dengan sistem antrean. Faktor-faktor yang berpengaruh terhadap barisan antrean dan pelayanannya adalah sebagai berikut:

1. Distribusi Kedatangan (Pola Kedatangan)

2. Distribusi Waktu Pelayanan (Pola Pelayanan)

3. Fasilitas Pelayanan

4. Disiplin Pelayanan

5. Ukuran dalam Antrean

6. Sumber Pemanggilan 


\subsubsection{Distribusi Kedatangan (Pola Kedatangan)}

Menurut Kakiay (2004), distribusi kedatangan para pelanggan biasanya diperhitungkan melalui waktu antar kedatangan, yaitu waktu antar kedatangan dua pelanggan yang berurutan pada suatu fasilitas pelayanan. Pada sistem antrean, distribusi kedatangan merupakan faktor penting yang berpengaruh besar terhadap kelancaran pelayanan. Distribusi kedatangan terbagi dua, yaitu:

a. Kedatangan secara individu (single arrivals)

b. Kedatangan secara berkelompok (bulk arrivals)

\subsubsection{Distribusi Waktu Pelayanan (Pola Pelayanan)}

Menurut Kakiay (2004), distribusi pelayanan ditentukan oleh waktu pelayanan, yaitu waktu yang dibutuhkan untuk melayani pelanggan pada fasilitas pelayanan. Distribusi waktu pelayanan berkaitan dengan berapa banyak fasilitas pelayanan yang dapat disediakan. Distribusi waktu pelayanan terbagi menjadi dua komponen penting, yaitu:

a. Pelayanan secara individual (single service)

b. Pelayanan secara kelompok (bulk service)

\subsubsection{Fasilitas Pelayanan}

Menurut Kakiay (2004), fasilitas pelayanan berkaitan erat dengan baris antrean yang akan dibentuk. Desain fasilitas pelayanan ini dapat dibagi menjadi tiga bentuk, yaitu:
a. Bentuk series
b. Bentuk paralel
c. Bentuk network station

\subsubsection{Displin Pelayanan}

Menurut Siagian (1987), disiplin antrean merupakan pedoman keputusan yang digunakan untuk menyeleksi individu atau kelompok yang memasuki antrean untuk dilayani terlebih dahulu. Terdapat empat jenis disiplin antrean yang biasa terjadi dalam sistem antrean, yaitu sebagai berikut:
a. Pertama Masuk Pertama Keluar (FIFO)
b. Terakhir Masuk Pertama Keluar (LIFO)
c. Pelayanan dalam Urutan Acak (SIRO)
d. Pelayanan Berdasarkan Prioritas (PRI)

\subsubsection{Ukuran dalam Antrean}

Menurut Kakiay (2004), besarnya antrean pelanggan yang akan memasuki fasilitas pelayanan pun perlu diperhatikan. Ada dua desain yang dapat dipilih untuk menentukan besarnya antrean, yaitu:

a. Ukuran kedatangan secara tidak terbatas (infinite quеие)

b. Ukuran kedatangan secara terbatas (finite queue)

\subsubsection{Sumber Pemanggilan}

Menurut Kakiay (2004), dalam fasilitas pelayanan yang berperan sebagai sumber pemanggilan dapat berupa mesin maupun manusia. Bila ada sejumlah mesin yang rusak maka sumber pemanggilan akan berkurang dan tidak dapat melayani pelanggan. Terdapat dua bentuk sumber pemanggilan, yaitu:

a. Sumber pemanggilan terbatas (finite calling source)

b. Sumber pemanggilan tidak terbatas (infinite calling source) 


\subsection{Struktur Dasar Sistem Antrean}

Menurut Subagyo et al. (1992), ada empat model struktur antrean dasar yang umum terjadi dalam seluruh sistem antrean, antara lain:
a. Satu Antrean Satu Pelayanan (Single Channel-Single Phase)
b. Satu Antrean, Beberapa Pelayanan Seri (Single Channel-Multiphase)
c. Satu Antrean Beberapa Pelayanan Paralel (Multichannel-Single Phase)
d. Beberapa Antrean Beberapa Pelayanan Paralel (Multichannel-Multiphase)

\subsection{Notasi Kendall}

Pada pengelompokan model antrean yang berbeda-beda digunakan suatu notasi yang disebut dengan Notasi Kendall. Notasi yang sering dipergunakan karena beberapa alasan. Diantaranya, karena notasi tersebut merupakan alat yang efisien untuk mengidentifikasi tidak hanya model-model antrean, tetapi juga asumsi-asumsi yang harus dipenuhi (Subagyo et al, 1992).

Format umum model:

$$
(a / b / c):(d / e / f)
$$

dimana:

$a$ : Distribusi kedatangan (arrival distribution).

$b$ : Distribusi waktu pelayanan (service time distribution).

$c$ : Jumlah tempat pelayanan (dengan $c=1,2,3, \ldots \infty$ ).

$d$ : Disiplin pelayanan misalkan FIFO, LIFO, SIRO, PRI.

$e$ : Jumlah maksimum pelanggan yang diizinkan dalam sistem.

$f$ : Sumber pemanggilan.

\subsection{Ukuran Steady State}

Steady state merupakan kondisi sewaktu sifat-sifat sistem tidak berubah dengan berjalannya waktu (konstan), $\rho$ didefinisikan sebagai perbandingan antara rata-rata pelanggan yang datang $(\lambda)$ dengan rata-rata pelanggan yang telah dilayani per satuan waktu $(\mu)$, atau dapat dituliskan sebagai berikut:

$$
\rho=\frac{\lambda}{c \mu}
$$

dengan c merupakan jumlah fasilitas pelayanan yang tersedia. Dalam kondisi steady state, diharapkan bahwa rata-rata pelanggan yang datang memiliki nilai yang sebanding dengan rata-rata pelanggan yang telah dilayani atau dapat dikatakan rata-rata pelanggan yang datang tidak melebihi rata-rata pelanggan yang telah dilayani $(\lambda<c \mu)$, sehingga jika $\rho<1$ maka dapat diartikan memenuhi kondisi steady-state atau kondisi ketika sifat-sifat suatu sistem tak berubah dengan berjalannya waktu (konstan).

\subsection{Uji Kolmogorov Smirnov}

Menurut Daniel (1989), apabila sampel yang ditarik dari populasi-populasi yang tidak diketahui, maka digunakan metode-metode keselarasan (goodness of fit) untuk menentukan sampai seberapa jauh data sampel yang teramati cocok dengan model yang ditawarkan. Terdapat metode keselarasan yang paling umum digunakan yaitu uji keselarasan Kolmogorov-Smirnov.

Menurut Daniel (1989), asumsi dalam uji Kolmogorov Smirnov adalah data terdiri atas hasil pengamatan bebas $\mathrm{N}_{1}, \mathrm{~N}_{2}, \ldots, \mathrm{N}_{\mathrm{i}}$, yang merupakan sebuah sampel acak berukuran $\mathrm{i}$ dari suatu fungsi distribusi yang belum diketahui dan dinyatakan dengan $\mathrm{F}_{0}(\mathrm{n})$. Adapun langkah-langkah uji Kolmogorov Smirnov sebagai berikut:

a. Menentukan Hipotesis 
$\mathrm{H}_{0}$ : Distribusi sampel mengikuti distribusi yang ditetapkan

$\mathrm{H}_{1}$ : Distribusi sampel tidak mengikuti distribusi yang ditetapkan

b. Menentukan Taraf Signifikansi

Di sini akan digunakan $\alpha$

c. Statistik Uji

$\mathrm{D}=\sup \left|\mathrm{S}(\mathrm{x})-\mathrm{F}_{0}(\mathrm{x})\right|$

dengan:

$\mathrm{S}(\mathrm{x})$ : fungsi peluang kumulatif yang dihitung dari data sampel

$\mathrm{F}_{0}(\mathrm{x})$ : fungsi distribusi yang dihipotesiskan (fungsi peluang kumulatif)

d. Kriteria Uji

Tolak $\mathrm{H}_{0}$ jika pada taraf signifikansi $\alpha$ jika nilai $\mathrm{D} \geq$ nilai $\mathrm{D}_{\text {tabel }}(1-\alpha)$, atau jika nilai sig $<$ nilai $\alpha$. $\mathrm{D}_{\text {tabel }}(\alpha)$ adalah nilai kritis yang diperoleh dari tabel Kolmogorov-Smirnov.

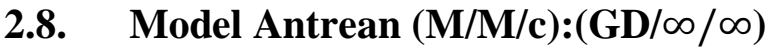

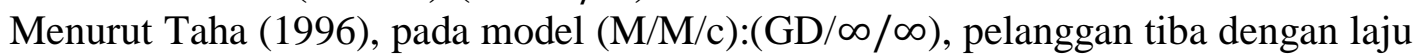
konstan, maksimum $c$ pelanggan dapat dilayani secara bersamaan, dan laju pelayanan per pelayanan adalah konstan. Pengaruh dari penggunaan $c$ pelayanan yang pararel adalah mempercepat laju pelayanan dengan memungkinkan dilakukannya beberapa pelayanan secara bersamaan. Jika jumlah pelanggan dalam sistem adalah $n$ sama dengan atau lebih besar dari $c$, maka laju keberangkatan gabungan dari sistem tersebut adalah $c \mu$. Jika $n$ lebih kecil dari $c$, maka laju pelayanannya $n \mu$. Maka probabilitas untuk $n$ pelanggan dapat ditulis sebagai berikut:

$$
\begin{gathered}
p_{n}=\left\{\begin{array}{l}
\frac{\lambda^{n}}{n ! \mu^{n}} p_{0}, \quad 0 \leq n \leq c \\
\frac{\lambda^{n}}{c ! c^{n-c} \mu^{n}} p_{0}, \quad n>c
\end{array}\right. \\
p_{0}=\left\{\sum_{n=0}^{c-1} \frac{\rho^{n}}{n !}+\frac{\rho^{c}}{c !\left(1-\frac{\rho}{c}\right)}\right\}^{-1}, \quad \frac{\rho}{c}<1
\end{gathered}
$$

Rumus untuk mencari ukuran-ukuran kinerja pada model antrean (M/M/c):(GD/œ/ $\infty)$ adalah sebagai berikut:

$$
\begin{array}{ll}
L_{q}=\frac{\rho^{c+1}}{(c-1) !(c-\rho)^{2}} p_{0} & L_{s}=L_{q}+\rho \\
W_{q}=\frac{L_{q}}{\lambda} & W_{s}=W_{q}+\frac{1}{\mu}
\end{array}
$$

\subsection{Model Antrean (G/G/c):(GD/ $\infty / \infty)$}

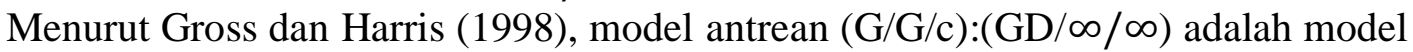
antrean dengan pola kedatangan berdistribusi umum (general) dan pola pelayanan berdistribusi umum (general) dengan jumlah fasilitas pelayanan sebanyak $c, c=1,2,3, \ldots$. Disiplin antrean yang digunakan pada model ini adalah umum yaitu FIFO (First In First Out), kapasitas maksimum yang diperbolehkan dalam sistem adalah tak hingga, dan 
memiliki sumber pemanggilan tak hingga.Untuk penghitungan jumlah pelanggan yang diperkirakan dalam antrean $\left(L_{q}\right)$ didasarkan pada ukuran kinerja pada model $(\mathrm{M} / \mathrm{M} / \mathrm{c}):(\mathrm{GD} / \infty / \infty)$. Rumus untuk mencari ukuran-ukuran kinerja pada model $(\mathrm{G} / \mathrm{G} / \mathrm{c}):(\mathrm{GD} / \infty / \infty)$ adalah sebagai berikut :

$L_{q}=\frac{\rho^{c+1}}{(c-1) !(c-\rho)^{2}} p_{0} \frac{\mu^{2} v(t)+v\left(t^{\prime}\right) \lambda^{2}}{2}=L_{q M / M / c} \frac{\mu^{2} v(t)+v\left(t^{\prime}\right) \lambda^{2}}{2}$

dengan:

$v(t)$ adalah varian dari waktu pelayanan

$v\left(t^{\prime}\right)$ adalah varian dari waktu antar kedatangan
$L_{s}=L_{q}+\rho$
$W_{q}=\frac{L_{q}}{\lambda}$
$W_{s}=W_{q}+\frac{1}{\mu}$

\section{METODOLOGI PENELITIAN}

\subsection{Jenis dan Sumber Data}

Data yang digunakan adalah data primer yaitu data yang diperoleh dengan pengamatan dan pencatatan langsung dari obyek penelitian. Penelitian dilakukan dengan mengambil sampel data selama 6 hari, yaitu pada hari Senin sampai dengan hari Sabtu. Sampel tersebut dianggap telah mewakili hari kerja dan akhir pekan. Dengan asumsi bahwa pola kedatangan dan pola keberangkatan pelanggan dilayani pada Terminal Bus Tirtonadi tidak berubah, sehingga dapat mewakili populasi hari lainnya.

\subsection{Variabel Penelitian}

a. Data jumlah dan waktu kedatangan bus nonpatas antarkota antar provinsi dan antarkota dalam provinsi jalur timur

b. Data jumlah dan waktu pelayanan bus nonpatas antarkota antar provinsi dan antarkota dalam provinsi jalur timur

\subsection{Langkah-Langkah Penelitian}

1. Menentukan tempat penelitian dan metode yang akan digunakan

2. Melakukan penelitian secara langsung di Terminal Bus Tirtonadi Surakarta untuk mendapatkan data jumlah kedatangan, data waktu kedatangan, data banyaknya pelayanan dan data waktu pelayanan dalam satuan waktu yang telah ditetapkan.

3. Data yang diperoleh harus memenuhi kondisi steady-state.

4. Melakukan uji kecocokan distribusi untuk kedatangan dan pengunjung terlayani dengan menggunakan uji Kolmogorov Smirnov.

5. Menentukan model antrean yang sesuai. Dilihat dari distribusi kedatangan, distribusi pelayanan, banyaknya server (jumlah pelayanan), disiplin antrean yang digunakan (FIFO, LIFO, SIRO atau Prioritas), kapasitas dalam sistem dan sumber pemanggilan.

6. Menentukan kinerja sistem, yaitu jumlah pelanggan yang diperkirakan dalam sistem (Ls), jumlah pelanggan yang diperkirakan dalam antrean (Lq), waktu menunggu dalam sistem (Ws), dan waktu menunggu dalam antrean (Wq).

7. Membuat hasil dan pembahasan yang diperoleh suatu model yang optimal.

8. Mengambil kesimpulan mengenai pelayanan di Terminal Tirtonadi Kota Surakarta secara keseluruhan. 


\section{HASIL DAN PEMBAHASAN}

Terminal Tirtonadi jalur timur adalah bagian dari terminal Tirtonadi yang dimana bus-bus yang datang dan berangkat dari dan ke arah timur kota Surakarta yaitu Surabaya, Karanganyar, Wonogiri, Purwodadi dan Pedesaan. Sistem antrean bus di Terminal Tirtonadi jalur timur adalah sebagai berikut :

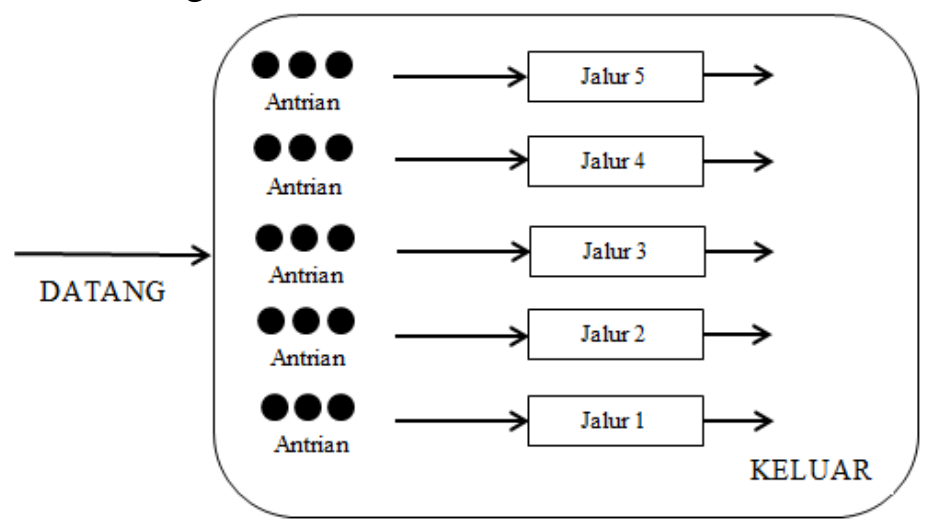

Gambar 1. Sistem Antrean Bus Nonpatas Terminal Timur Tirtonadi

\subsection{Analisis Steady State}

Analisis data awal akan dimulai dengan menghitung faktor utilisasi $(\rho)$ untuk tiaptiap pelayanan per jalur. Ukuran steady state dari kinerja sistem pelayanan dapat diperoleh dari data jumlah kedatangan pada obyek penelitian dan data waktu pelayanan dengan menghitung probabilitas dari sistem pelayanan. Kondisi steady state harus terpenuhi sehingga dapat diketahui bahwa jumlah rata-rata pelanggan yang datang lebih kecil dari rat-rata laju pelayanan agar sistem pelayanan mencapai keadaan yang stabil. Berikut hasil perhitungan nilai $\rho$ :

Tabel 1. Analisis Steady State

\begin{tabular}{|c|c|c|c|c|}
\hline Tujuan & $\mathrm{c}$ & $\lambda$ & $\mu$ & $\rho=\frac{\lambda}{\mathrm{c} \mu}$ \\
\hline Surabaya & 1 & 8,563549 & 9,402641 & 0,91076 \\
\hline Karanganyar & 1 & 6,280717 & 7,475955 & 0,840122 \\
\hline Wonogiri & 1 & 8,138928 & 10,57379 & 0,769726 \\
\hline Purwodadi & 1 & 4,264044 & 5,034524 & 0,86496 \\
\hline Pedesaan & 1 & 8,888798 & 35,89064 & 0,247663 \\
\hline
\end{tabular}

Dari Tabel diatas dapat diketahui bahwa nilai tingkat kegunaan fasilitas pelayanan kelima jalur sudah kurang dari satu. Sehingga dapat disimpulkan bahwa sistem antrean kelima jalur tersebut sudah steady-state, yaitu rata-rata tingkat kedatangan bus tidak melebihi ratarata tingkat pelayanan.

\subsection{Uji Distribusi}

Uji kecocokan distribusi yang digunakan untuk menguji data waktu antar kedatangan dan waktu pelayanan bus nonpatas di tiap-tiap jalur Terminal Tirtonadi bagian timur. Pada uji tersebut akan diketahui apakah data waktu antar kedatangan dan waktu pelayanan bus nonpatas pada tiap-tiap jalur berdistribusi Eksponensial.

\subsubsection{Uji Distribusi Data Waktu Kedatangan}

Berikut ini adalah hasil uji distribusi dari data waktu antar kedatangan bus nonpatas setiap 60 menit untuk kelima jalur bus. 
Tabel 2. Uji Distribusi Data Waktu Kedatangan

\begin{tabular}{|c|c|c|c|c|c|}
\hline Tujuan & D & $\mathrm{D}^{*}(\alpha)$ & $p$-value & Keputusan & Kesimpulan \\
\hline Surabaya & 0,290 & 0,063549 & 0,000 & $\mathrm{H}_{0}$ ditolak & $\begin{array}{l}\text { tidak berdistribusi } \\
\text { Eksponensial }(\mathrm{G})\end{array}$ \\
\hline Karanganyar & 0,149 & 0,075093 & 0,000 & $\mathrm{H}_{0}$ ditolak & $\begin{array}{l}\text { tidak berdistribusi } \\
\text { Eksponensial }(\mathrm{G})\end{array}$ \\
\hline Wonogiri & 0,193 & 0,065357 & 0,000 & $\mathrm{H}_{0}$ ditolak & $\begin{array}{l}\text { tidak berdistribusi } \\
\text { Eksponensial (G) }\end{array}$ \\
\hline Purwodadi & 0,528 & 0,0 & 0,000 & $\mathrm{H}_{0}$ ditolak & $\begin{array}{l}\text { tidak berdistribusi } \\
\text { Eksponensial }(\mathrm{G})\end{array}$ \\
\hline Pedesaan & 0,073 & 0,062933 & 0,014 & $\mathrm{H}_{0}$ ditolak & $\begin{array}{l}\text { tidak berdistribusi } \\
\text { Eksponensial }(\mathrm{G})\end{array}$ \\
\hline
\end{tabular}

\subsubsection{Uji Distribusi Data Waktu Pelayanan}

Berikut ini adalah hasil uji distribusi dari data waktu pelayanan bus nonpatas setiap 60 menit untuk kelima jalur bus.

Tabel 3. Uji Distribusi Data Waktu Pelayanan

\begin{tabular}{|c|c|c|c|c|c|}
\hline Tujuan & $\mathrm{D}$ & $\mathrm{D}^{*}(\alpha)$ & $\mathrm{p}$-value & Keputusan & Kesimpulan \\
\hline Surabaya & 0,308 & 0,063549 & 0,000 & $\mathrm{H}_{0}$ ditolak & $\begin{array}{c}\text { tidak berdistribusi } \\
\text { Eksponensial }(\mathrm{G})\end{array}$ \\
\hline Karanganyar & 0,174 & 0,074752 & 0,000 & $\mathrm{H}_{0}$ ditolak & $\begin{array}{c}\text { tidak berdistribusi } \\
\text { Eksponensial (G) }\end{array}$ \\
\hline Wonogiri & 0,160 & 0,065282 & 0,000 & $\mathrm{H}_{0}$ ditolak & $\begin{array}{c}\text { tidak berdistribusi } \\
\text { Eksponensial (G) }\end{array}$ \\
\hline Purwodadi & 0,231 & 0,090869 & 0,000 & $\mathrm{H}_{0}$ ditolak & $\begin{array}{c}\text { tidak berdistribusi } \\
\text { Eksponensial }(\mathrm{G})\end{array}$ \\
\hline Pedesaan & 0,256 & 0,063001 & 0,000 & $\mathrm{H}_{0}$ ditolak & $\begin{array}{c}\text { tidak berdistribusi } \\
\text { Eksponensial }(\mathrm{G})\end{array}$ \\
\hline
\end{tabular}

\subsection{Model Sistem Antrean}

Berdasarkan hasil analisis steady-state serta uji kecocokan distribusi waktu kedatangan dan waktu pelayanan bus nonpatas dapat ditentukan bahwa model sistem antrean untuk kelima jalur adalah (G/G/1):(GD/o/ $/ \infty)$. Model tersebut adalah model sistem antrean dengan waktu antar kedatangan berdistribusi umum (general) dan waktu pelayanan berdistribusi umum (general), dengan jumlah sistem pelayanan sebanyak 1 jalur, displin antrean yang digunakan adalah yang pertama datang yang pertama dilayani (FIFO), serta jumlah kapasitas pelanggan yang datang dan sumber pemanggilan tak terbatas.

Guna mendapatkan perhitungan kinerja yang lebih maksimal, maka diperlukan uji untuk mengetahui distribusi dengan menggunakan software Arena pada kelima jalur bus tersebut. Berikut adalah hasil distribusi yang diperoleh dari software Arena dan telah di uji distribusinya menggunakan uji Kolmogorov Smirnov: 
Tabel 4. Uji Distribusi Hasil Arena Data Waktu Kedatangan

\begin{tabular}{|c|c|c|c|c|c|c|}
\hline Tujuan & $\mathrm{D}$ & $\mathrm{D}^{*}(\alpha)$ & $p$-value & Keputusan & Kesimpulan & $\mathrm{D}$ \\
\hline Surabaya & 0,029 & 0,063549 & $>0,015$ & $\begin{array}{c}\mathrm{D}<\mathrm{D}^{*}(\alpha) \\
p \text {-value }>\alpha \\
\mathrm{H}_{0} \text { diterima }\end{array}$ & $\begin{array}{c}\text { Berdistribusi } \\
\text { Erlang }\end{array}$ & 0,029 \\
\hline Karanganyar & 0,0412 & 0,075093 & $>0,015$ & $\begin{array}{c}\mathrm{D}<\mathrm{D}^{*}(\alpha) \\
\text {-value }>\alpha \\
\mathrm{H}_{0} \text { diterima }\end{array}$ & $\begin{array}{c}\text { Berdistribusi } \\
\text { Erlang }\end{array}$ & 0,0412 \\
\hline Wonogiri & 0,039 & 0,065357 & $>0,015$ & $\begin{array}{c}\mathrm{D}<\mathrm{D}^{*}(\alpha) \\
p \text {-value }>\alpha \\
\mathrm{H}_{0} \text { diterima }\end{array}$ & $\begin{array}{c}\text { Berdistribusi } \\
\text { Gamma }\end{array}$ & 0,039 \\
\hline Purwodadi & 0,0426 & 0,091072 & $>0,015$ & $\begin{array}{c}\mathrm{D}<\mathrm{D}^{*}(\alpha) \\
p \text {-value }>\alpha \\
\mathrm{H}_{0} \text { diterima }\end{array}$ & $\begin{array}{c}\text { Berdistribusi } \\
\text { Erlang }\end{array}$ & 0,0426 \\
\hline Pedesaan & 0,0432 & 0,062933 & $>0,015$ & $\begin{array}{c}\mathrm{D}<\mathrm{D}^{*}(\alpha) \\
p \text {-value }>\alpha \\
\mathrm{H}_{0} \text { diterima }\end{array}$ & $\begin{array}{c}\text { Berdistribusi } \\
\text { Weibull }\end{array}$ & 0,0432 \\
\hline
\end{tabular}

Tabel 5. Uji Distribusi Hasil Arena Data Waktu Pelayanan

\begin{tabular}{|c|c|c|c|c|c|c|}
\hline Tujuan & D & $\mathrm{D}^{*}(\alpha)$ & $p$-value & Keputusan & Kesimpulan & D \\
\hline Surabaya & 0,0279 & 0,063549 & $>0,015$ & $\begin{array}{c}\mathrm{D}<\mathrm{D}^{*}(\alpha) \\
p \text {-value }>\alpha \\
\mathrm{H}_{0} \text { diterima }\end{array}$ & $\begin{array}{l}\text { Berdistribusi } \\
\text { Erlang }\end{array}$ & 0,0279 \\
\hline Karanganyar & 0,0373 & 0,074752 & $>0,015$ & $\begin{array}{l}\mathrm{D}<\mathrm{D}^{*}(\alpha) \\
p \text {-value }>\alpha \\
\mathrm{H}_{0} \text { diterima }\end{array}$ & $\begin{array}{l}\text { Berdistribusi } \\
\text { Weibull }\end{array}$ & 0,0373 \\
\hline Wonogiri & 0,0311 & 0,065282 & $>0,015$ & $\begin{array}{l}\mathrm{D}<\mathrm{D}^{*}(\alpha) \\
p \text {-value }>\alpha \\
\mathrm{H}_{0} \text { diterima }\end{array}$ & $\begin{array}{l}\text { Berdistribusi } \\
\text { Weibull }\end{array}$ & 0,0311 \\
\hline Purwodadi & 0,0464 & 0,090869 & $>0,015$ & $\begin{array}{c}\mathrm{D}<\mathrm{D}^{*}(\alpha) \\
p \text {-value }>\alpha \\
\mathrm{H}_{0} \text { diterima }\end{array}$ & $\begin{array}{l}\text { Berdistribusi } \\
\text { Weibull }\end{array}$ & 0,0464 \\
\hline Pedesaan & 0,0322 & 0,063001 & $>0,015$ & $\begin{array}{c}\mathrm{D}<\mathrm{D}^{*}(\alpha) \\
p \text {-value }>\alpha \\
\mathrm{H}_{0} \text { diterima }\end{array}$ & $\begin{array}{l}\text { Berdistribusi } \\
\text { Lognormal }\end{array}$ & 0,0322 \\
\hline
\end{tabular}

Berdasarkan uji kecocokan distribusi ini, dapat disimpulkan bahwa model antrean

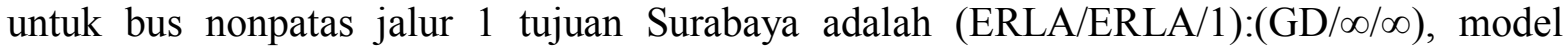
antrean bus nonpatas jalur 2 tujuan Karanganyar adalah (ERLA/WEIB/1):(GD/ $/ \infty / \infty)$, model

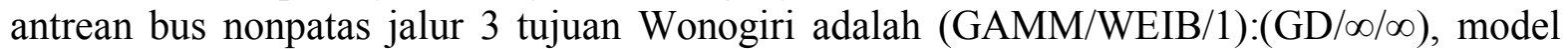

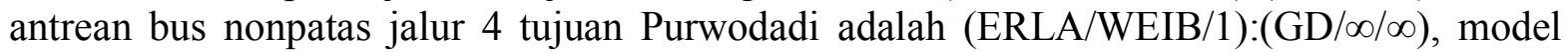

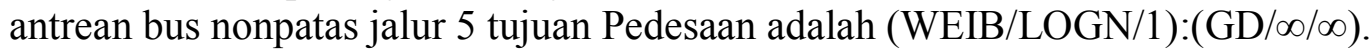




\subsection{Analisis Ukuran Kinerja Sistem Antrean Terminal Timur Tirtonadi}

Setelah dilakukan analisis steady state dan uji kecocokan model, langkah selanjutnya yaitu melakukan analisis kinerja sistem antrean dengan menggunakan program WINQSB akan diperoleh tabel hasil akhir antrean sebagai berikut:

Tabel 6. Perolehan Hasil Akhir Analisis Antrean

\begin{tabular}{|c|c|c|c|c|c|c|c|c|c|}
\hline Tujuan & $\mathrm{c}$ & $\lambda$ & $\mu$ & $\rho$ & Model & $\mathrm{L}_{\mathrm{s}}$ & $\mathrm{L}_{\mathrm{q}}$ & $\mathrm{W}_{\mathrm{s}}$ & $\mathrm{W}_{\mathrm{q}}$ \\
\hline Surabaya & 1 & 8,56 & 9,40 & 0,91 & $\begin{array}{c}\text { (ERLA/ERLA/1): } \\
(\mathrm{GD} / \infty / \infty)\end{array}$ & 2,73 & 1,82 & 0,32 & 0,21 \\
\hline Karanganyar & 1 & 6,28 & 7,47 & 0,84 & $\begin{array}{c}(\mathrm{ERLA} / \mathrm{WEIB} / 1): \\
(\mathrm{GD} / \infty / \infty)\end{array}$ & 3,05 & 2,21 & 0,49 & 0,35 \\
\hline Wonogiri & 1 & 8,14 & 10,57 & 0,77 & $\begin{array}{c}(\mathrm{GAMM} / \mathrm{WEIB} / 1 \\
\text { ):(GD/o//) }\end{array}$ & 1,93 & 1,16 & 0,24 & 0,14 \\
\hline Purwodadi & 1 & 4,26 & 5,03 & 0,86 & $\begin{array}{c}(\mathrm{ERLA} / \mathrm{WEIB} / 1): \\
(\mathrm{GD} / \infty / \infty)\end{array}$ & 2,56 & 1,72 & 0,60 & 0,40 \\
\hline Pedesaan & 1 & 8,89 & 35,89 & 0,25 & $\begin{array}{c}(\mathrm{WEIB} / \mathrm{LOGN} / 1): \\
(\mathrm{GD} / \infty / \infty)\end{array}$ & 0,31 & 0,06 & 0,03 & 0,006 \\
\hline
\end{tabular}

\section{KESIMPULAN}

Berdasarkan pada hasil analisis penelitian yang telah dilakukan, dapat disimpulkan beberapa hal sebagai berikut:

1. Sistem antrean bus Terminal timur Tirtonadi tujuan Surabaya, Karanganyar, Wonogiri, Purwodadi dan Pedesaan sudah stabil karena memiliki nilai utilitas kurang dari 1.

2. Model sistem antrean bus Terminal timur Tirtonadi untuk ke 5 jalur dengan tujuan Surabaya, Karanganyar, Wonogiri, Purwodadi dan Pedesaan yaitu (G/G/1):(GD/o/ $/ \infty)$. Model tersebut merupakan model antrean dengan waktu kedatangan dan waktu pelayanan berdistribusi umum (General), terdapat 1 sistem pelayan (shelter) bus yang beroperasi tiap jalur, aturan pelayanan pertama datang pertama dilayani (FIFO), kapasitas pelayanan tidak terbatas, dan sumber pemanggilan tidak terbatas.

3. Berikut model untuk antrean bus beserta distribusinya yang diperoleh dengan menggunakan software Arena. Model sistem antrean bus nonpatas jalur 1 tujuan Surabaya adalah (ERLA/ERLA/1):(GD/o/ / ), model antrean bus nonpatas jalur 2

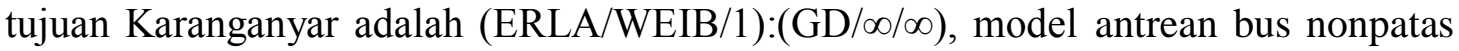
jalur 3 tujuan Wonogiri adalah (GAMM/WEIB/1):(GD/o/ $/ \infty)$, model antrean bus

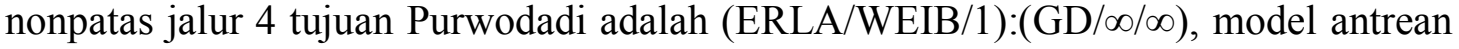

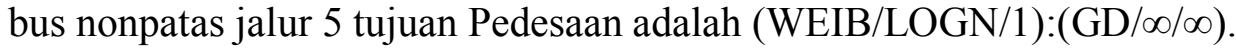

4. Berdasarkan nilai dari ukuran-ukuran kinerja sistem antrean yang diperoleh secara keseluruhan dapat disimpulkan bahwa kelima jalur antrean bus nonpatas Terminal timur Tirtonadi Kota Surakarta memiliki kondisi yang sudah baik.

\section{DAFTAR PUSTAKA}

Daniel, W. W. 1989. Statistika Nonparametrik Terapan (terjemahan). Jakarta: PT. Gramedia.

Gross, D and Harris, C. M. 1998. Fundamental of Queueing Theory: Third Edition. New York: John Willey and Sons, Inc.

Kakiay, T. J. 2004. Dasar Teori Antrian Untuk Kehidupan Nyata. Yogyakarta: Andi.

Kundu, D. dan Manglick, A. 2004. Discriminating Beetween The Weibull and Log-normal Distribution. Journal of Applied Statistical Sciences. 
Kurniasih, R. dan Pramesti, G. 2013. Distribusi Erlang dan Penerapannya. Surakarta: Jurnal Seminar Nasional Pendidikan Matematika : 223 - 236

Nursetyo, G. 2010. Kajian Manajemen Sirkulasi Terminal Bus (Studi Kasus: Terminal Bus Tirtonadi Surakarta). Jurnal Teknik Sipil dan Arsitektur. Vol. 8., No. 12 A.

Siagian, P. 1987. Penelitian Operasional: Teori dan Praktek. Jakarta: Universitas Indonesia Press.

Siswanto, 2006, Operations Research, Jilid 2, Jakarta: Erlangga

Subagyo, P. Asri M. dan Handoko T. H. 1992. Dasar-dasar Operation Research. Yogyakarta: BPFE

Taha, H. A. 1996. Riset Operasi: Jilid Dua. Jakarta: Binarupa Aksara.

Wackerly D.D., Mendenhall W., Scheaffer R.L. 2008. Mathematical Statistics With Application. Seventh Edition. Brooks / Cole., USA.

Walpole, R.E. dan R. H. Myers. 2012. Probability and Statistics for Engineers and Scientists. Pearson Education, Inc. Boston 